\title{
HEALTH ASPECTS OF PEACE-KEEPING OPERATIONS *
}

\author{
Colonel F. G. NEILD, M.R.C.S., L.R.C.P., D.P.H., D.I.H., Late R.A.M.C. \\ Headquarters, Southern Command \\ (A former Chief Medical Officer, Headquarters, United Nations Force in Cyprus \\ $(U . N . F . I . C Y P))$
}

Now that our defence effort is geared to Europe and of a lesser priority to the logistic support of a United Nations (U.N.) Force, perhaps a look at U.N. peace-keeping operations might be of interest and enable us to find out something of their characteristics. Since the formation of the U.N. there have been three major peace-keeping operations:
GAZA (U.N.E.F.)
December 1956 to May 1967.
CONGO (O.N.U.C.)
June 1960 to June 1964.
CYPRUS (U.N.F.I.CYP)
March 1964 to present time.

In only the last operation has the United Kingdom taken part and, in fact, it is the first time that a permanent member of the Security Council has ever been directly involved. This is because the selection of nations to take part in U.N. operations is a major exercise in political decision-making, so the provision of logistic units by countries such as the United Kingdom is less likely to cause argument and to arouse suspicion from the newly emerging states than the provision of teeth-arm units.

All U.N. operations have the twin aims of peace-keeping (usually the military task) and peace-making (the political task). Table I shows the organisation to achieve these twin aims in Cyprus, where the unfinished tasks of peace-keeping and achieving a unified island go on today as they have done since, following the Security Council resolution of 4 March 1964, U.N.F.I.CYP took over from the 3rd Division.

To bring the medical problems into perspective, Table II shows the comparative size of these U.N. Forces raised so far. In each operation contingents serve for six months only and arrive by air at light scales with, usually two medical officers. As all soldiers wear the powder-blue beret of the United Nations, very soon after arrival each man is immediately aware of himself as a member of an impartial force whose task is to prevent fighting, to restore and then to maintain law and order and eventually to gain a return to normal conditions.

\section{Organisation}

At the beginning of the U.N.E.F. operation, there being little co-ordination between the various medical units, no system of medical re-supply and no medical administrative instruction, it was soon clear that there was a need for central administration, and so the Commander of the largest medical contingent (Norwegian) was made Senior Medical Staff Officer (S.M.S.O.). Similar organisational problems had also to be resolved in both the O.N.U.C. and U.N.F.I.CYP operations. In the former an Indian

\footnotetext{
* As presented at the Deputy Director of Medical Services, Southern Command Study Period 25 October 1969.

NOTE: The views expressed in this article are exclusively those of the author, and do not necessarily reflect the policy of the United Nations, the Secretary-General, or the Commander of the United Nations Force in Cyprus.
} 
Table I

U.N.F.I.CYP.

Special Representative of Secretary General

$$
\text { Civilian Staff }
$$

Senior Legal/Political Adviser
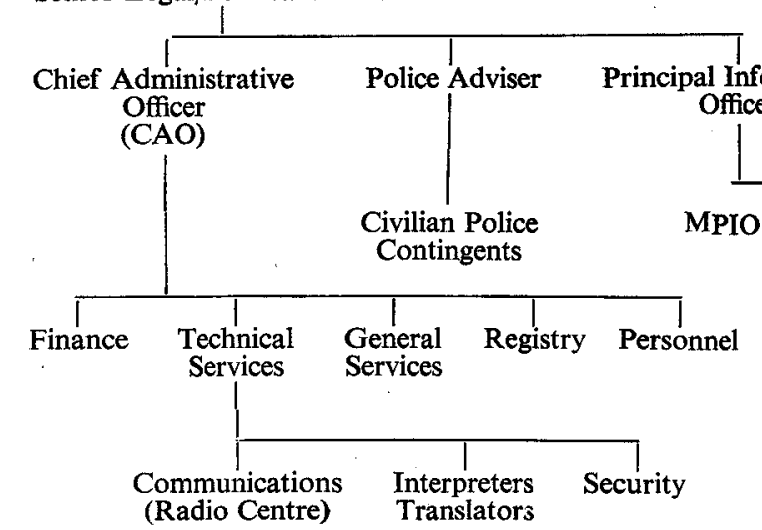

MPIO
Officer

Security

Kyrenia District $\quad$ Nicosia-West District $\quad$ Nicosia-East District $\quad$ Famagusta Zone Limassol Z

Engineer Det Signal Tp Austrian Field U.N.F.I.CYP. U.N.F.I.CYP. U.N.F.I.CYP. Provost U.N. Flight Det Sqn


Table II

United Nations operations

Size of Force and Nations providing contingents

\begin{tabular}{|c|c|c|c|c|c|}
\hline & & $\begin{array}{c}\text { Gaza } \\
1956-1967\end{array}$ & \multirow{2}{*}{\multicolumn{2}{|c|}{$\begin{array}{c}\begin{array}{c}\text { Congo } \\
1960-1964\end{array} \\
13800\end{array}$}} & $\begin{array}{l}\text { Cyprus } \\
1964^{-} ?\end{array}$ \\
\hline \multirow[b]{2}{*}{ Force } & Infantry & 2500 & & & 3000 \\
\hline & $\begin{array}{l}\text { Supporting including } \\
\text { Staff, Signals, Air and } \\
\text { Administrative units }\end{array}$ & 1000 & \multicolumn{2}{|c|}{2900} & 700 \\
\hline Date & & Sep 1966 & \multicolumn{2}{|c|}{ Feb 1962} & Jun 1968 \\
\hline Nations & & $\begin{array}{l}\text { Brazil } \\
\text { Denmark } \\
\text { Canada } \\
\text { India } \\
\text { Norway } \\
\text { Yugoslavia }\end{array}$ & $\begin{array}{l}\text { Argentina } \\
\text { Austria } \\
\text { Brazil } \\
\text { Canada } \\
\text { Ceylon } \\
\text { Denmark } \\
\text { Ethiopia } \\
\text { Fed. Malaya } \\
\text { Ghana } \\
\text { India }\end{array}$ & $\begin{array}{l}\text { Ireland } \\
\text { Italy } \\
\text { Liberia } \\
\text { Netherlands } \\
\text { Nigeria } \\
\text { Norway } \\
\text { Pakistan } \\
\text { Sierra Leone } \\
\text { Sweden } \\
\text { Tunisia }\end{array}$ & $\begin{array}{l}\text { Austria } \\
\text { Canada } \\
\text { Denmark } \\
\text { Finland } \\
\text { Ireland } \\
\text { Sweden } \\
\text { United Kingdom }\end{array}$ \\
\hline
\end{tabular}

was Assistant Director of Medical Services (A.D.M.S.), in the latter the Chief Medical Officer (C.M.O.) is British, as the logistical support, including base hospitals, comes from the Sovereign Base Areas (S.B.A.)-British Military Hospital, Dhekelia, and Princess Mary's Royal Air Force Hospital, Akrotiri, although the immediate hospital support for U.N.F.I.CYP is provided by the Austrian Field Hospital, located within five miles of Force Headquarters on Nicosia airfield.

In U.N.F.I.CYP the C.M.O. is technical medical adviser to the Force Commander. $\mathrm{He}$ is responsible for the overall co-ordination of medical care and casualty evacuation in U.N.F.I.CYP, the approval of repatriation medical boards, and is commander of the small medical detachment at H.Q. U.N.F.I.CYP which caters for H.Q. and British administrative sub-units (around 300 personnel). An important part of his duties is liaison between Greek-Cypriot and the Turkish-Cypriot medical authorities who had no common meeting ground. Earlier he was involved with the welfare problems of refugees but now these are all handled by the Operations (Economics) Branch.

The C.M.O. is assisted by a British Force Health Inspector, a Warrant Officer, Class I, who is responsible for advising contingent medical officers on all matters pertaining to hygiene and camp sanitation. The Force Health Inspector is also responsible for liaison between the Greek-Cypriot and the Turkish-Cypriot Public Health Departments and for the co-ordination of the island wide malaria control measures, particularly in 'Greenline' areas. In U.N.E.F. and O.N.U.C. on the other hand, with their many communicable disease problems, field hygiene teams were also found necessary. Additionally in O.N.U.C. much civilian work, due to the complete breakdown of the civilian medical services, had to be carried out and this was eventually handed over to World Health Organisation and Red Cross teams.

For administrative matters the C.M.O. dealt with Pers. 1, Logs 1 and the civilian Chief Administrative Officer (C.A.O.), as the Chief of Staff(C.O.S.) and Deputy Chief of Staff (D.C.O.S.) were almost entirely concerned with both operational and political 
liaison matters and were contingent commanders as well. It will be noted that there is no one in the equivalent position of a Colonel A.Q. as financial control was held by the C.A.O., who was also reponsible for the rear signal link to New York, while Pers. 1's duties were mainly advisory, as responsibility for discipline remained nationally in the hands of each contingent commander.

Medical policy for all contingents is laid down in 'Standing Operational Procedures ' (S.O.Ps) and in 'Personnel Instructions'. Notes on health in Cyprus, including immunisation requirements, are included in the latter for the briefing of all incoming contingents. Medical policy for contingent medical officers is further amplified by Standing Medical Administrative Instructions (S.M.A.I's), while M.A.Is containing medical staff lists and all routine medical information are issued monthly. The C.M.O. keeps himself informed by means of periodic returns from all Senior Medical Officers (S.M.O's) and hospitals and also by visiting contingents as often as possible.

\section{Hospital service}

At the start of the U.N.E.F. operation there were two hospitals, but one year later, when the Force became centrally controlled, it was found that one was sufficient. The staff requirement for the hospital was found by experience to be a surgeon as Commanding Officer, one assistant surgeon, one internist, one pathologist and one radiologist, together with a dental officer with necessary staff and equipment. Consultant opinion in the other specialities was obtained locally in the Government hospitals in Gaza and the Tel Hashomer Hospital at Tel Aviv. In the O.N.U.C. operation surgical teams of several nationalities as well as an Austrian Field Hospital took over various deserted civilian hospitals, while in the capital, Leopoldville, now Kinshasa, an Indian General Hospital was located.

At the start of the U.N.F.I.CYP operations all admissions were made to the two S.B.A. hospitals, but shortly afterwards, with the arrival of the Austrian Field Hospital, the majority of admissions were undertaken by that unit. If more complicated methods of treatment were required patients were sent to the S.B.A. hospitals or repatriated by civilian or military aircraft. At Table III is given the organisation of the Austrian Field

Table III

Austrian Field Hospital (8 officers and 45 enlisted men)

(50 beds)

Commanding Officer

\begin{tabular}{|c|c|c|c|c|c|}
\hline $\begin{array}{l}\text { HQ Section } \\
\text { (21) }\end{array}$ & $\begin{array}{l}\text { QM Section } \\
(6)\end{array}$ & $\underset{(13)}{\text { Surgical }}$ & $\begin{array}{l}\text { Medical } \\
\text { (4) }\end{array}$ & OP/Lab/Dispenser & $\begin{array}{l}\text { Dental } \\
\text { (2) }\end{array}$ \\
\hline $\begin{array}{l}\text { Adjutant } \\
\text { Liaison Officer }\end{array}$ & Quartermaster & Surgeon & Internist & Medical officer & Dental officer \\
\hline $\begin{array}{l}3 \text { Clerks } \\
2 \text { Telephone } \\
\text { operators } \\
9 \text { Drivers } \\
5 \text { General duty } \\
\text { + messes }\end{array}$ & $\begin{array}{l}5 \text { General } \\
\text { duty. }\end{array}$ & $\begin{array}{l}12 \text { Technicians } \\
\text { to provide } 2 \\
\text { operating teams, } \\
\text { including } \\
\text { radiographers }\end{array}$ & $\begin{array}{l}3 \text { Medical } \\
\text { assistants }\end{array}$ & $\begin{array}{l}2 \text { Medical assistants } \\
2 \text { Laboratory } \\
\text { assistants } \\
1 \text { Dispenser }\end{array}$ & $\begin{array}{l}1 \text { Dental } \\
\text { technician }\end{array}$ \\
\hline Unit transport: & $\begin{array}{l}1 \text { C.O's V/W c } \\
2 \text { V/W ambula } \\
2 \text { V/W buses }\end{array}$ & $\begin{array}{l}\text { ar } \\
\text { nces }\end{array}$ & Local incren & t: 1 Landrover & \\
\hline
\end{tabular}


Hospital which will be seen to be very similar to the U.N.E.F. equivalent. It is equipped for 50 beds and its bed occupancy was around 40 per cent, being higher in the hot weather than the cold. Every Saturday the C.M.O. did a liaison round and to eliminate catering problems, the menu was circulated in four languages.

\section{Contingent medical services}

Each contingent, approximately of battalion strength, usually had a S.M.O. (except the British) and one other medical officer, assisted by medical personnel, in some cases including a hygiene technician. They took care of the daily sick (military), carried out civilian labour pre-employment examinations and ran the sick bay, variously called unit aid station, medical centre, infirmary and polyclinic. The sick bays varied in size from two to fifteen beds, the latter being so because of language difficulties. Although English was the official language in a number of contingents it was unfamiliar to their soldiers, so that these contingents preferred to treat their own sick rather than admit them to hospital accompanied by interpreters. About half the contingents had their own dental officer. Each contigent had one or two Landrover or Volvo ambulance vehicles, the latter being equipped with direct speaking radio to the contingent Headquarters.

Sick rates varied widely and were almost impossible to compare statistically. There were many reasons. In one contingent a minor scratch, ache or pain would be dealt with by a medical assistant (unrecorded) but in another seen by a medical officer (recorded). Additionally some soldiers serving on a six months' contract in U.N.F.I.CYP, who in their own country had to pay a proportion of the medical or dental fees, perhaps when no cost was involved, took the opportunity to consult dental or medical officers more freely. In the same way, when contract personnel were due to return at the end of their tour, there could be a tendency to attribute any blemish which might have occurred as due to overseas service. Although personnel are examined and found 100 per cent fit before arrival, since only the British and Canadians use the P.U.L.H.E.E.M.S. system of medical classification which makes the distinction between personnel who can serve world-wide and those who are restricted to a temperate climate, a number of the latter category presented themselves as skin or ear problems after arrival in Cyprus. An additional point was that as contingents rotated half-yearly, new personnel were undergoing acclimatisation every six months instead of at the beginning of the three year tour of the S.B.A. troops. Leave to the Near East was another problem. Most entitled personnel took their fortnight's leave there and a number came back with gastro-enteritis of one sort or another, and in some cases with the severer forms of venereal disease.

The daily routine hygiene work in a contingent was performed by its own medical staff. On C.M.O. inspections where it was noted that there were adverse sanitary conditions, it was usually found that there was a block in communications between the medical and regimental officers or between the contingent and H.Q. U.N.F.I.CYP. It was not always appreciated in contingents that regimental officers were responsible for the health of their men and this was made more difficult to get over when a number of medical officers were civilians, with little or no military training, on a two or three months' contract which included a short local leave in the Near East. Only the British, Canadian and Southern Irish had permanent cadres of regular full time medical officers. 
The others were part-time general practitioners controlled by one or two full-time regular medical officers at their national Ministry of Defence to whom they sent regular detailed reports.

A complete hygiene inspection of a contingent would take several days. This was because the contingent was generally split into company camps and these again were split into smaller groups ranging from three to ten men. These smaller groups occupied what is termed an outpost (O.P.), all situated on tactical features between the GreekCypriot National Guard and the Turkish-Cypriot Freedom Fighters. Cooking was done either centrally in company camps, meals being taken out twice a day in containers, or on the O.P., with fresh or compo rations according to contingent choice. In U.N.F.I.CYP. there were six variations on the basic ration scale incorporating national differences such as maple syrup for the Canadians, Kerry Gold butter for the Irish, rye crisp bread for the Swedes and frankfurters for the Danes, and there were five types of bread, all supplied from the logistical base of Dhekelia. Accommodation ranged from tentage and hutting in the country, to schools and deserted buildings in towns. Sanitary facilities at O.Ps ranged from deep trench latrines, through buckets and Elsans up to elegant water closets in luxury hotels. From time to time when major rotations took place, 1 Hygiene Wing at Dhekelia ran a one-week course so that each contingent would have at least three men trained in the rudiments of camp hygiene and sanitation. Except for the British and Canadians, these courses were new and much appreciated by the personnel of other contingents.

Pay, perhaps the only subject to provide inter-contingent comment, was complicated by the varying national contribution to the cost of the Force, whether contingents accepted U.N. allowances, and also by regular service and volunteer systems.

\section{Casualty evacuation}

From the first days of U.N.E.F., transport of serious cases over long distances was made by air, Canadian Otter aircraft being used, while ambulances were used only for station duties. For seriously wounded or ill patients beyond the scope of the U.N.E.F. hospital, evacuation was made out of the area by Canadian C-119s to the United States Navy Hospital in Naples from where cases could be forwarded to hospitals dealing with other specialities in Germany. Later, arrangements were made to transfer these types of cases locally to hospitals in Tel Aviv, Cairo or Beirut.

Similar principles applied in O.N.U.C. Initial evacuation was by means of Beavers or Sikorskys to the various hospital areas where ambulances were used for station duties. It must be remembered that O.N.U.C. was operating in a country only marginally smaller than India and one of its brigades was keeping the peace in an area the size of France. From the main hospital areas to the Indian General Hospital in Leopoldville, charter D.C's 3, 4 and 6 were used, the distance from Kamina the main southern base, being around 1,000 miles to Leopoldville. The longer term patients went weekly by the Canadian Yukon flight via Idris to Pisa where they were dispersed to their home countries.

In U.N.F.I.CYP. where the distances were smaller, no contingent being more than 70 miles from a main hospital, primary evacuation was by road transport unless a genuine emergency existed, when helicopter evacuation was made either in a Wessex (Royal Air Force) or on the Stokes litter of a Sioux (Army Air Corps). Moreover, 
U.N.F.I.CYP. facilities have occasionally been made available, on a humanitarian basis, for the evacuation by road or by helicopter of injured or wounded Cypriots of both communities, where the Force Commander or the C.O.S. considered that to do so would serve to reduce intercommunal strife or otherwise further the U.N.F.I.CYP. mandate.

There was no set holding policy, but as service in U.N.F.I.CYP. was for only six months, personnel who had contracted a serious illness or injury were repatriated as soon as possible, the medical board being approved by the C.M.O. and sanctioned by the Force Commander. The report had to recommend whether a medical attendant should travel and the means of transport as, for reasons of economy, whenever possible aircraft for rotating personnel and contingent supplies were used. However, in a number of cases of serious emergency, civilian aircraft regardless of expense were used, particularly when there was a likelihood of long and unexpected delays en route.

\section{Medical Supplies}

In U.N.E.F. all contingents arrived with sufficient medical supplies for six months and in case of emergency local purchase was authorised. Later a Medical Equipment Depot was built up in their maintenance area. This depot was slow in operation due to the inherent delay in the special U.N. purchasing system, for first requisitions had to reach New York before tenders could be invited. After receipt they were checked and only then could purchases be made. All this took time, six months to one year, since most items were manufactured in the United States or Canada and then sent on by ship. Contingents, however, also obtained emergency items from their own national resources. In O.N.U.C. a similar system was in operation. In U.N.F.I.CYP. contingents (except the British) brought sufficient medical supplies to last them six months. In the case of emergencies, some were authorised local purchase, some used the S.B.A. hospital medical stores and some had emergency arrangements with their own national resources, routine national re-supply medical indents for contingents varying between two to eight weeks. The British contingent used a monthly indent on one of the S.B.A. hospitals. The medical supplies, other than those used by the British from the S.B.A. hospitals, were then costed and charged against U.N. as was the cost of an admission to a S.B.A. hospital bed at approximately $£ 10$ per day.

\section{Summary and discussion}

In spite of the turnover of U.N. medical personnel coming from seven different nations for only six months' service overseas and in some cases as little as two or three, it is considered that the teamwork and co-operation between them reached a very high standard.

The C.M.O. has been provided by the contingent contributing the main medical support and his work is largely co-ordination and health education in contingents and mediation between the local civilian medical authorities. A knowledge of a second language is useful.

In peace-keeping operations the casualty rates are mainly from injuries and, as the length of tour overseas is only six months, the surgical requirement is for a field medical unit which can be backed up, if air transportation is used, by base hospitals at some distance. 


\section{REFERENCES}

- HoRn, Carl von. (1966). Soldiering for Peace. Cassells, London.

KLUGer, T., LoNnum, A. and UduUs, L. (1963). Medical Service in United Nations Emergency Force. Rev. int. Serv. Santé Armées. 36, Suppl. au no 5 Mai.

Melsom, M. A. and LASSEN, E. H. P. (1962). Medicine in the Congo. J. roy. Army med. Cps. 102, 29.

PERvulekso, W. (1964). The employment of the Austrian Medical Contingents during the United Nations (Police) Action in the Congo. Rev. int. Serv. Santé Armées. 37, 329.

SOLDIER (1969). Volume 25, No. 4

VerRIER, A. (1966). Guyana and Cyprus. Techniques of Peace-keeping. J. roy. Unit. Ser. Instn. CXI, 298.

To the Army at Home

Honorary Consultant

Mr. J. B. Blaikley, C.B.E., F.R.C.S., F.R.C.O.G., has been appointed Honorary Consultant in Obstetrics \& Gynaecology to the Army at Home as from 28 November 1969, in succession to Sir Arthur Bell.

Order of St. John of Jerusalem

Those recently appointed to, or promoted in, the Most Venerable Order of the Hospital of St. John of Jerusalem include:

As Officers (Brothers). Colonel R. L. Marks, O.B.E., M.B., Ch.B. 